\title{
Seasonal and Spatial Distribution of Bacterioplankton in a Fluvial-lagunar System of a Tropical Region: Density, Biomass, Cellular Volume and Morphologic Variation
}

\author{
Magnólia Fernandes Florêncio de Araújo ${ }^{1 *}$ and Mirna Januária Leal Godinho ${ }^{2}$ \\ ${ }^{1}$ Universidade Federal do Rio Grande do Norte; Centro de Biociências; Departamento de Microbiologia e \\ Parasitologia; Campus Universitário Lagoa Nova; BR 101; 59072-970; Lagoa Nova; Natal - RN - Brasil. \\ ${ }^{2}$ Universidade Federal de São Carlos; Centro de Ciências Biológicas e da Saúde; Departamento de Ecologia e \\ Biologia evolutiva; Rodovia Washington Luis (SP-310); Km 235; 13565-905; São Carlos - SP - Brasil
}

\begin{abstract}
The temporal and spatial fluctuations of Bacterioplankton in a fluvial-lagunar system of a tropical region (Pitimbu River and Jiqui Lake, RN) were studied during the dry and the rainy periods. The bacterial abundance varied from 2.67 to 5.1 Cells $10^{7} \mathrm{~mL}^{-1}$ and did not show a typical temporal variation, presenting only small oscillations between the rainy and the dry periods. The bacterial biomass varied from $123 \mu \mathrm{gC} L^{-1}$ to $269 \mu \mathrm{gC} L^{-1}$ in the sampling sites and the average cellular volume varied from 0.12 to $0.54 \mu^{3}$, showing a predominance of the rods. The temperature showed a positive correlation with the cellular volume of the rods $(R=0.55 ; p=0.02)$ and vibrio $(R=0.53 ; p=0.03)$. Significant spatial differences of biomass (Mann Whitney: $p=0.01$ ) and cellular volume of the morphotypes (Mann Whitney: $p=0.003$ ) were found between the sampling sites. The strong positive correlations of the water temperature and oxygen with bacterioplankton showed a probable high bacterial activity in this system.
\end{abstract}

Key words: Bacterioplankton, biomass, morphologic variation, tropical environment

\section{INTRODUCTION}

The bacteria are among the most abundant planktonic organisms of the lakes (Lewis, 1986; Lindström, 2001) and rivers (Gocke and Rheinheimer, 1988; Leff et al., 1998; Leff, 2000). They are a basic component in the aquatic food webs, contributing significantly to the cycling of nutrients and the flow of energy (Azam et al., 1983; Gurung et al., 2002). Their temporal and longitudinal variation can influence the ecology of specific populations and modify the structure and function of the microbial community (Liu and Leff, 2002).

The study of the temporal alterations in the composition of the bacterial morphotypes can lead to the elucidation of important variations in the density and biomass of Bacterioplankton in an aquatic system (Kirschner and Velimirov, 1997). The cellular size is the result of the growth and the frequency of the division. The balance between these two basic processes depends on the basic environmental conditions, such as quantity and quality of nutrients and physical and chemical variables of the water (Sime-Ngando et al., 1991;

${ }^{*}$ Author for correspondence 
Jugnia et al., 1998). Changes in the composition of the bacterial community occur because of the mechanisms of the predation (Jurgens et al., 1999; Masín et al., 2003); the nutritional quality of the environment (Castillo et al., 2003; Crump et al., 2003) or due to the host-specific viral lyses (Fuhrman, 1999).

The regulating mechanisms of the bacterial abundance and biomass in the aquatic ecosystems have been the focus of investigation in many works, but such studies are related, to a large extent, to the lakes and the rivers of the temperate regions (del Giorgio and Gasol, 1995; Kirschner and Velimirov, 1997; Liu and Leff, 2002; Izaguirre et al., 2003). Moreover, the variables that regulate their diversity and abundance are little understood and, sometimes, controversial, despite the great interest in the role of the heterotrophic bacteria in the aquatic environments. The historically alternated periods of low and high rainfall and the typically elevated levels of insolation of tropical regions can influence the development and the composition of the microbial communities. The studies carried out in the aquatic environments of these regions are a contribution to the characterization of the effect of the high temperatures, rain and drought on the bacterial populations.

This work aimed to characterize the bacterial compartment in regard to its abundance, biomass and cellular volume, and to describe their morphologic variations, in a fluvial-lagunar system located in a hot climate region. The possible regulating factors of these variations are discussed.

\section{Study Area}

Pitimbu River (PR) is located in the eastern part of Rio Grande do Norte state (between the $5^{\circ} 50^{\prime}$ and $6^{\circ}$ parallels $00^{\prime}$ of southern latitude and meridians $35^{\circ} 05^{\prime}$ and $35^{\circ} 25^{\prime}$ of West longitude), a region with a predominantly sub-humid type climate (tropically rainy with dry summers), in northeast Brazil. The River presents perennial in all its extension. Its waters contribute to the formation of Jiqui Lake (JL), which supplies about 190,000 inhabitants. The shed of Pitimbu River sub-basin has been used for industrial and tourist activities, generating speculations on the increase of its pollution levels. The characteristics of the two study areas are shown in Table 1.

Table 1- Morphometric characteristics of Pitimbu River and Jiqui Lake

\begin{tabular}{lcc}
\hline Characteristics & Pitimbu River & Jiqui Lake \\
\hline Length & $31 \mathrm{Km}$ & $1,210 \mathrm{~m}$ \\
Width & - & $200 \mathrm{~m}$ \\
Water volume & - & $466,093 \mathrm{~m}^{3}$ \\
Total area & $126.45 \mathrm{Km}^{2}$ & $15.25 \mathrm{he}$ \\
Maximum depth & $1.5 \mathrm{~m}$ & $5.5 \mathrm{~m}$ \\
Minimum depth & $0.1 \mathrm{~m}$ & $0.5 \mathrm{~m}$ \\
Mean depth & $0.5 \mathrm{~m}$ & $2.5 \mathrm{~m}$ \\
\hline
\end{tabular}

\section{MATERIALS AND METHODS}

\section{Sampling}

The intensive samples (groups of three to five samplings inside of, the maximum, 10 days) were carried out in the three rainy periods (June/2001; April/2002; June/2002) and two dry periods (December/2001; December/2002). In Jiqui Lake, the samples were collected from the central part of its deeper region $(3 \mathrm{~m})$. From epilimnetic layer $(0.5 \mathrm{~m}$ depth), samples were obtained directly using a test tube of $100 \mathrm{~mL}$ and, in the deep part,
$0.5 \mathrm{~m}$ above the surface of the sediment, a 05 liter Van Dorn bottle was used. In the Pitimbu River, the water samples were collected at the three sampling points along its longitudinal axis (PR1, PR2 and PR3). At each sampling site, samples were collected directly in a central point between the two margins. Aliquots for the physical, chemical and biological analyses were removed.

\section{Meteorological, physical and chemical analyses} Monthly precipitation data, speed of the wind, solar radiation and air temperature were supplied 
by the Meteorological Station of the Federal University of Rio Grande do Norte, located 6 to 13 $\mathrm{km}$ from the sampling sites. The temperature of the water and the dissolved oxygen were measured with a portable digital oximeter (Digimed, model DM4). The measurements of oxygen were periodically tested by the Winkler method (Golterman et al., 1978). A portable digital potentiometer (WTM, model $\mathrm{pH} 330 \mathrm{i}$ ) was used to measure $\mathrm{pH}$. The concentrations of total nitrogen (N-total) and total phosphorus (P-total) were determined following Valderrama (1981). A $30 \mathrm{~cm}$ Secchi disk was used to measure the water transparency, and the total solids were measured according to APHA (1998).

\section{Biological analyses}

Duplicated samples for the bacterial analysis were fixed with tamponated formaldehyde ( $2 \%$ final concentration; $\mathrm{pH}$ 7.4). Sub-samples of 1 or $2 \mathrm{~mL}$ were stained with acridine orange $(0.01 \%)$ and filtered in a black polycarbonate membrane filter (Millipore, GTBP; $0.2 \mu \mathrm{m}$ pore size), using a support filter (Poretics; $0.45 \mu \mathrm{m}$ ) to distribute the samples uniformly. The used solutions were filtered in a membrane with a $0.2 \mu \mathrm{m}$ pore size. The filters were mounted between the cover and the coverslip, covered with a non- fluorescent immersion oil and counted in an epifluorescence microscope (Olympus BX41; magnification $\mathrm{x}$ 1250; dichroic mirror DM500; excitement filter BP460-490 and barrier filter BA520IF). At least 300 bacterial cells were counted in every filter in 10 to 20 microscopical fields. Two blanks consisting of mili-Q autoclaved water were prepared for each set of processed samples and treated identically to the environmental samples. The blanks were consistently low (always less than $1 \%$ of the bacterial counting). Length and width of $>30$ cells were obtained with a micrometric ocular. The bacteria were classified in three groups, on the basis of their morphology: rods, cocci and vibrios. The cellular volumes were calculated through the formula: $(\pi / 4) \times(\mathrm{W} 2 \times[\mathrm{L}-(\mathrm{W} / 3))]$, where $\mathrm{W}$ is the width and $\mathrm{L}$ is the length of the cell. For the coccids cells $\mathrm{W}=\mathrm{L}$ (Bratbak, 1993). An allometrous conversion formula was used in the calculation of the cellular carbon content: CC (fg $\mathrm{C})=120 . \mathrm{V}^{0,72}$, where: $\mathrm{CC}=$ carbon content and $\mathrm{V}=$ cellular volume $\left(\mu \mathrm{m}^{3}\right)$. This formula, proposed by Simon and Azam (1989) and recalculated by Norland (1993) was considered by Posch et al. (2001), to be better adjusted to cells dyed with the acridine orange. Chlorophyll $a$ was determined according to Lorenzen (1967) after filtration of the samples in a glass fiber filter (GFC, Whatman) and extraction in $90 \%$ ethanol.

\section{Statistical Analysis}

Spearman correlation coefficients were calculated to determine the relations between the different variables. The Mann Whitney U-Test was used to verify possible significant differences in the variables between the lake and the river during rainy and dry periods.

\section{RESULTS}

\section{Meteorological and Environmental variables}

Mean values, minimum and maximum of data obtained in the Pitimbu River and Jiqui Lake are shown in Tables 2 and 3. The samples were taken during the two characteristically rainy and dry periods. The dissolved oxygen and the levels of chlorophyll $a$ were higher in the lake than in the river, and $\mathrm{pH}$ was lightly acidic at all the sampling points $(5.8-6.2)$. The transparency of the water was higher during dry periods $(\geq 2.0 \mathrm{~m})$, coinciding with the lower precipitation indices. The total-P and total-N concentrations had ample variations between the sites and climatic periods, with the higher values (Total-N: $835 \mu \mathrm{g} \mathrm{L}^{-1}$; Total-P: 24.9 $\mu \mathrm{g} \mathrm{L}^{-1}$ ) occurring at the most impacted point (PR2). The total solids were higher $\left(\geq 380 \mathrm{mg} \mathrm{L}^{-1}\right)$ during the rainy periods, at all the sampling sites. Data of Jiqui Lake varied significantly between the dry and the rainy periods in relation to total- $\mathrm{N}$ (Mann Whitney: $\mathrm{U}=12 ; \mathrm{p}=0.016$ ) and dissolved oxygen (Mann Whitney: $\mathrm{U}=12.5 ; \mathrm{p}=0.018$ ). Compared to the river sites, the lake presented higher levels of the dissolved oxygen and lower levels of total phosphorus. On basis of Total-N, Total-P and chlorophyll levels, the system could be characterized as mesotrophic.

\section{Bacterioplankton abundance}

Bacterial density was higher in the lake than in the river. Sampling sites PR1 and PR2 presented the highest densities during the dry periods while PR3 site and the lake showed higher densities during the rainy periods (Fig. 1). Statistically significant variation of the total abundance of bacterioplankton did not occur between the sampling sites. 


\section{Density of bacterial morphotypes}

Bacterial morphotypes densities did not show a remarkable temporal variation, occurring only small oscillations between the rainy and the dry periods. Rods-like cells were numerically predominant at all the points of the river and, mainly, at the lake, influencing considerably the total abundance of bacterioplankton. Cocci solitary forms were the second most abundant morphological group. Vibrios were less numerous, occurring in higher density only during the dry periods, at all the river stations (Fig. 2).

Table 2 - Mean, minimum and maximum of meteorological variables from Pitimbu River and Jiqui Lake, during the study period

\begin{tabular}{lcc}
\hline Climatic Period & $\begin{array}{c}\text { Precipitation } \\
(\mathbf{m m})\end{array}$ & Air Temperature $\left({ }^{\circ} \mathbf{C}\right)$ \\
\hline Jun - Ago/2001 & 260 & 25.8 \\
(Rainy Period) & $(104 ; 374)$ & $(24.9 ; 25.9)$ \\
Set -F ev/2002 & 51 & 28,5 \\
(Dry period) & $(14 ; 114)$ & $(26.2 ; 29.7)$ \\
Mar - Ago/2002 & 281 & 26 \\
(Rainy period) & $(123 ; 480)$ & $(25.1 ; 26.9)$ \\
Set-Dez/2002 & 39 & 28.2 \\
(Dry period) & $(10 ; 98)$ & $(26.4 ; 29.3)$ \\
\hline
\end{tabular}

Table 3 - Mean, minimum and maximum of environmental variables from Pitimbu River and Jiqui Lake, during the study period

\begin{tabular}{lcccc}
\hline & \multicolumn{2}{c}{ Pitimbu River } & & $\begin{array}{c}\text { Jiqui Lake } \\
\text { Mean (min-max) }\end{array}$ \\
\hline Variables & PR1 & PR2 & PR3 & \\
Temperature $\left({ }^{\circ} \mathrm{C}\right)$ & 27.3 & 2.1 & 27.7 & 27.8 \\
& $(25.8-28.8)$ & $(26.6-28)$ & $(27-28.5)$ & $(26-31)$ \\
Oxygen & 4.8 & 4.3 & 4.9 & 5.9 \\
$\left(\mathrm{mg} \mathrm{L}^{-1}\right)$ & $(3.9-6)$ & $(3.8-4.6)$ & $(4.4-5.6)$ & $(5.1-6.8)$ \\
Transparency $(\mathrm{m})$ & - & - & - & 2,1 \\
& & & & $(1,7-2,8)$ \\
$\mathrm{pH}$ & 5.8 & 6.1 & 6.1 & 6.2 \\
& $(5.5-6.1)$ & $(5.9-6.3)$ & $(5.9-6.4)$ & $(5.5-6.7)$ \\
Chlorophyll a $\left(\mu \mathrm{g} \mathrm{L}{ }^{-1}\right)$ & 4.1 & 2.89 & 3.1 & $5.8(1.8-10.1)$ \\
& $(3.04-5.47)$ & $(1.45-4.4)$ & $(1.62-4.9)$ & \\
Total-N & 245 & 370 & 420 & $352(112-784)$ \\
$(\mu \mathrm{g} \mathrm{L}-1)$ & $(161-405)$ & $(164-835)$ & $(205-687)$ & \\
Total-P & 10.4 & 13.6 & 7.6 & 10.2 \\
$\left(\mu \mathrm{g} \mathrm{L}{ }^{-1}\right)$ & $(6.9-16.9)$ & $(5-24.9)$ & $(3.2-11.4)$ & $(4.1-17)$ \\
Total solids $\left(\mathrm{mg} \mathrm{L}^{-1}\right)$ & 100 & 138 & 171 & $87(40-200)$ \\
& $(80-120)$ & $(52-416)$ & $(50-475)$ & \\
\hline
\end{tabular}




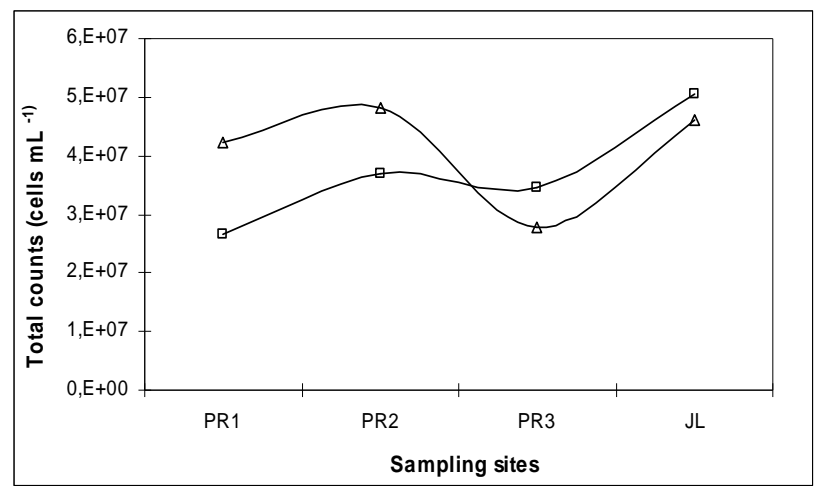

Figure 1 - Changes in total bacterial density during dry $(\triangle)$ and rainy $(\square)$ periods. PR1, PR2 and PR3 = Pitimbu River; JL = Jiqui Lake
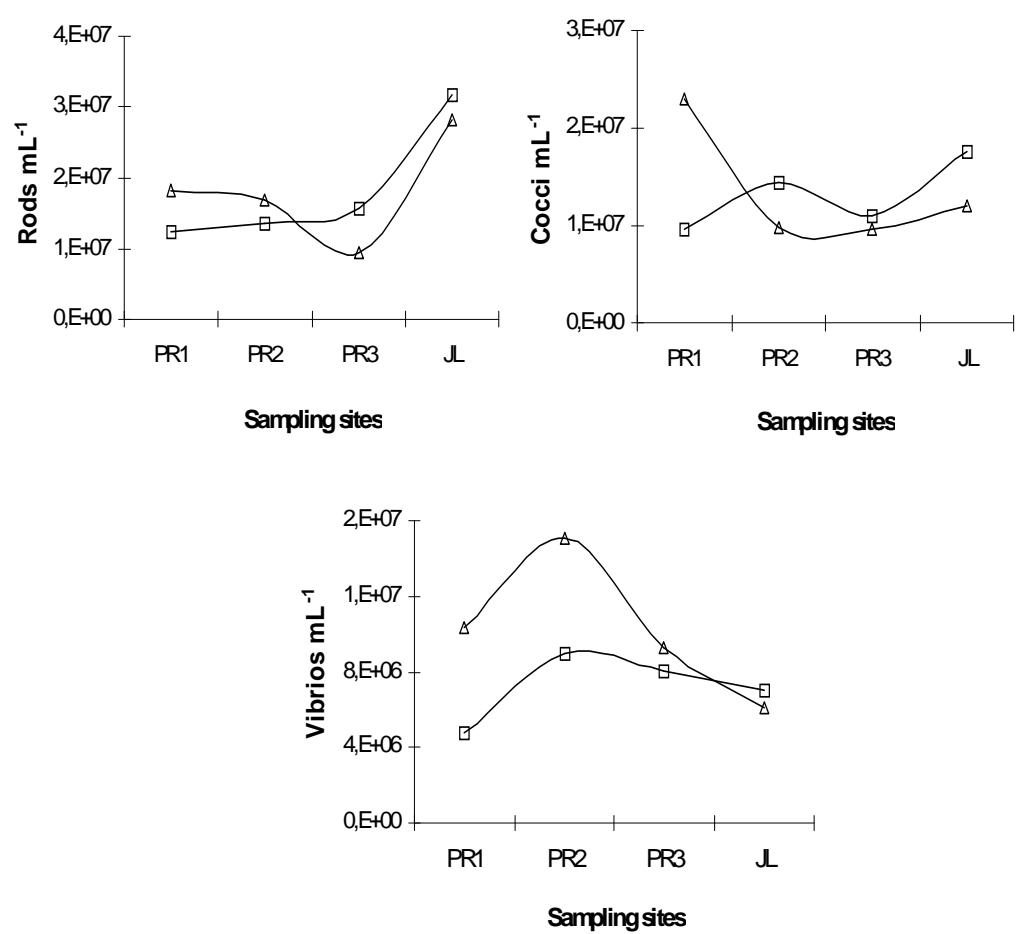

Figure 2 - Changes in bacterial morphotypes density during dry $(\triangle)$ and rainy $(\square)$ periods. PR1, PR2 and PR3 = Pitimbu River; JL = Jiqui Lake.

During the rainy periods, the number of rods increased in the river-lake direction and during the dry periods an accentuated decrease at the station PR3 occurred (22\% to $13 \%)$. The density of the cocci was higher at PR1 during the dry period $(45 \%)$ in relation to the rainy periods $(18 \%)$, when it had been the less abundant form. Vibrios, the forms with lower densities, were more significant in the river than in the lake, especially during the dry periods and predominantly at the station PR2 $(37 \%)$.

\section{Biomass and cellular Volume}

The mean of the bacterial biomass varied

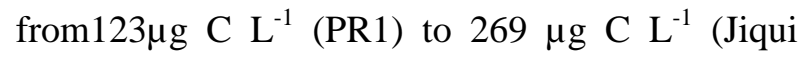


Lake), being significantly higher in the lake, during the rainy period (Fig. 3).

The mean of the cellular volumes (Fig. 4) varied from $0.12 \mu \mathrm{m}^{3}$ (cocci) to $0.54 \mu \mathrm{m}^{3}$ (rods). The rods presented the largest cellular volume (0.39 $0.54 \mu \mathrm{m}^{3}$ ) during the dry seasons as well as during the rainy ones. In the lake, there was an increase in the cellular volume of all the morphotypes during the rainy periods and in the river, only vibrio had a higher cellular volume during the dry periods, varying from 0.25 to $0.29 \mu \mathrm{m}^{3}$. Strong correlations were detected between the temperature and the cellular volume of the rods $(0.55 ; \mathrm{p}=0.02)$ and vibrios $(0.53 ; \mathrm{p}=0.03)$ and between the oxygen and the cellular volume of the cocci $(0.76 ; \mathrm{p}=0.002)$, rods $(0.59 ; \mathrm{p}=0.01)$ and vibrios $(0.60 ; \mathrm{p}=0.01)$.

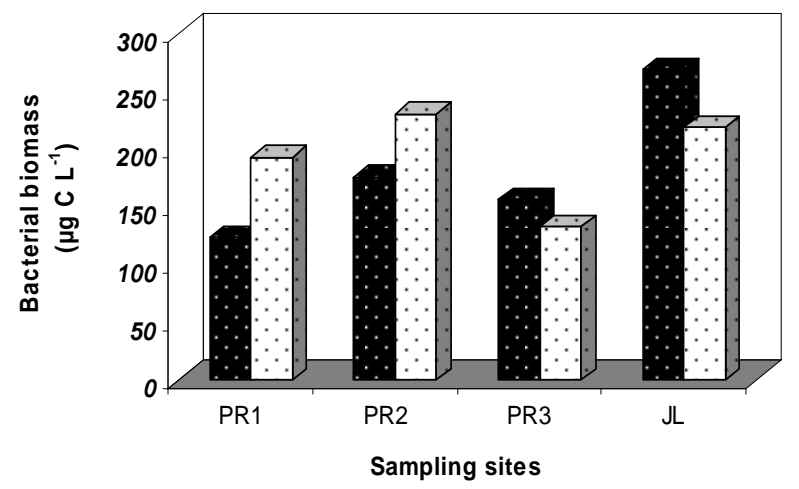

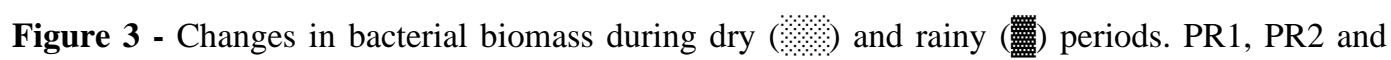
PR3 = Pitimbu River; JL = Jiqui Lake.
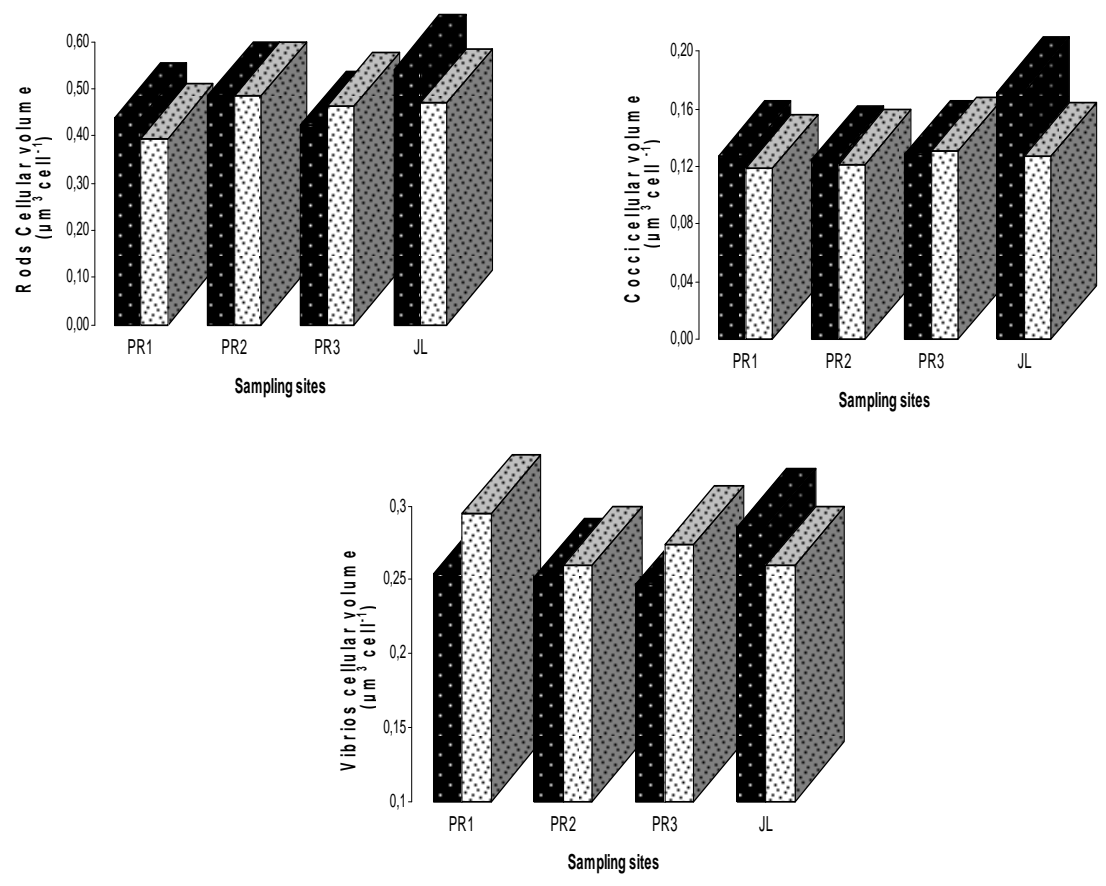

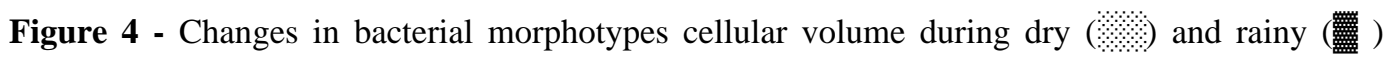
periods. PR1, PR2 and PR3 = Pitimbu River; JL = Jiqui Lake. 
The water temperature was the only significantly different variable between the dry and the rainy periods (Mann Whitney: $\mathrm{p}=0.002$ ). In relation to the sampling sites, significant variation occurred in the cellular volume of the cocci, rods and vibrios (Mann Whitney: $\mathrm{p}=0.003$ ), oxygen (Mann Whitney: $\mathrm{p}=0.006$ ) and bacterial biomass (Mann Whitney: $\mathrm{p}=0.01$ ) which was consistently higher in the lake.

\section{DISCUSSION}

The bacterial density found in this study $\left(10^{7}\right.$ cells $\mathrm{mL}^{-1}$ ) was among the highest cited by studies carried out in freshwater systems with the different trophic levels (Jugnia et al., 1998; Jezbera et al., 2003) and could be associated to the low depth of the environment, which made possible the introduction of the bacteria of the sediment in to the water column. Moreover, the good exploitation of carbon, through the bacterial activity, cuold also favor the growth of their populations. The mean of total bacterial biomass in the present study (123 $269 \mu \mathrm{gC} \mathrm{L}^{-1}$ ) was situated below those already registered in a tropical freshwater region. Erikson et al. (1999) found a biomass between 240 and 930 $\mu \mathrm{gC} \mathrm{L}{ }^{-1}$ in a tropical lake and Farjalla et al. (2001) obtained biomasses between 480 and $1432 \mu \mathrm{gC} \mathrm{L}^{-1}$ in coastal lakes of southeastern Brazil. In relation to the biomass, significant differences between the lotic and lentic regions of the Pitimbu-Jiqui system were found, clearly favoring to the bacterial development in the lacustrine part of the system. The average cellular volume found in this system $\left(0.12-0.54 \mu \mathrm{m}^{3}\right.$ cell) fitted among those cited in literature for the freshwater environments (Table 4).

Table 4 - Comparison between cellular volumes in freshwaters environments

\begin{tabular}{lccc}
\hline Environment & Cell. $\mathbf{V} .\left(\boldsymbol{\mu m}^{\mathbf{3}}\right)$ & Trophic state & References \\
\hline Lake Aydat (France) & $0.05-0.121^{*}$ & eutrophic & Sime-Ngando et al. (1991) \\
Lake Comwell (Canada) & $0.06-0.213^{*}$ & - & Sime-Ngando et al. (1991) \\
Monjolinho & $0.37-0.53^{*}$ & eutrophic & Seleghim, 1992 \\
Reserv. (Brazil) & & & Amblard et al. (1996) \\
Potable reserv (France) & $0.24-0.53$ & - & Kirshner and Velimirov \\
Danube River (Austria) & $0.043-0.129$ & mesotrophic & (1997) \\
& & Jugnia et al. (1998) \\
Lake Yaoundé (Cameron) & $0.050-0.20$ & mesotrophic- & Gurung et al. (2002) \\
Lake Biwa (Japão) & $0.08-0.14$ & eutrophic & Lind and Barcena (2003) \\
Lake Waco (EUA) & $0.12-0.21$ & mesotrophic & This study \\
Jiqui Lake (Brazil) & $0.28-0.36$ & &
\end{tabular}

*filamentous not included

Significant differences between the lotic and lentic regions of the Pitimbu-Jiqui system were found. According to Palumbo et al. (1984), variations found in the average of the cellular volume of the morphotypes reflected the differences in the taxes of growth or the physiological state of the bacterial community. The cellular volumes found in the lake were superior to the ones found in the river, mainly in the rainy period. This suggested the installation of the differences in the nutritional conditions of the environments (Lewis et al., 1986) and in the community composition, during the rainfall, which was reflected in the much higher biomass found in the lake. The use of these substrata assumeed the presence of populations with a capacity of enzymes-production to their processing, favoring their cycling (del Giorgio and Cole, 1998) and guaranteeing an energy profit that surpassed the high costs involved in this process.

Significant correlation between the phosphorous and nitrogen and the microbial variables, commonly cited as determinatives in the composition of the microbial community, was not observed in this study. Farjalla et al. (2001) found strong correlations between the phosphorous and the bacterial densities and the biomass in Brazilian coastal lakes, where this nutrient seemed to limitate the bacterial growth. Some laboratorial experiments have also demonstrated the importance of the nutrients for the 
bacterioplankton (Kísand et al., 2001; Muylaert et al., 2002; Castillo et al., 2003). The total solid substances which enter in the Pitimbu-Jiqui system, from the draining of adjacent lands and antropic activities (Oliveira, 1994; GuimarãesSegundo, 2002) can be important in aiding bacterial growth. In points with low phytoplanktonic biomass, as is the case of this system, the dissolved organic carbon of non-algal origin becomes the biggest power plant for bacteria (del Giorgio and Gasol, 1995; Petrucio et al., 2005). Since correlations between the chlorophyll $a$ and bacterial variables were not found, the importance of the arrival of the organic allochthonous and autochthonous substances from ressuspension and dealing with a low level environment - explained the elevated number and the high bacterial biomass.

Carvalho et al. (2003) and Coveney and Wetzel (1995) also did not find a relationship between the chlorophyll and the bacterioplankton, during the studies carried out in oligotrophic and mesotrophic environments. The dependence of bacterioplankton of dissolved organic carbon released by the phytoplankton (Kisand et al., 2001) and the effect of the bacterivory in the control of the populations (Krstulovic et al., 1997) was more typical in the eutrophized environments (Gonzalez et al., 2000). Moreover, the low levels of chlorophyll denoted the importance of bacterioplankton for the trophic structuring of this environment, where significant relation between the bacteria and the phytoplankton was not observed. This suggested that the dissolved organic carbon, generated from phytoplankton was not the most important substratum for the bacteria of the system, which agreed with the results found by Kirschner and Velimirov (1997) and Carvalho et al. (2003).

The abundance of bacterioplankton in the PitimbuJiqui system was high, in relation to others freshwater environments and the cellular and biomass volumes fitted into those already cited to the same trophic state environments. The temporal morphological variations occurred under the influence of precipitation and temperature, which seemed to be favorable to the bacterial multiplication during the dry and the rainy periods. The strong positive correlations of the water temperature and oxygen, with bacterioplankton suggested a high bacterial activity in this system. Future studies should be developed to confirm the hypotheses raised through these studies on the bacterial metabolism in this system and the possible role of the products of decomposition of aquatic macrophytes present in the system as a substratum for the growth of bacterial populations.

\section{ACKNOWLEDGEMENTS}

The authors wish to thank Drs. Ivaneide Soares and Renata Panosso for their commentaries in a preliminary version of this work. We are also grateful to Edson Santana and Renata Martins for their assistance in field and laboratory work. Magnólia Araújo received a doctorate scholarship from CAPES (Coordenação de Aperfeiçoamento de pessoal de ensino superior) - Ministério da Educação) and financial support from the Federal university of Rio Grande do Norte and Federal University of Sao Carlos, to this work.

\section{RESUMO}

A variação temporal e espacial do bacterioplâncton em um sistema fluvial-lagunar de região tropical foi estudada em períodos seco e chuvoso. As médias da abundância bacteriana variaram de 2,67 a $5,1 \times 10^{7}$ e não exibiram uma variação temporal marcante, tendo apresentado apenas pequenas oscilações entre os períodos chuvoso e seco. A biomassa bacteriana variou de $123 \mu \mathrm{g} \mathrm{C} \mathrm{L}^{-1}$ a $269 \mu \mathrm{g} \mathrm{C} \mathrm{L}^{-1}$ entre os locais de coleta e o volume celular médio de $0,12 \mu \mathrm{m}^{3}$ a $0,54 \mu \mathrm{m}^{3}$, ocorrendo predominância de bacilos. A temperatura mostrou correlação positiva com o volume celular de bacilos $(\mathrm{R}=0,55 ; \mathrm{p}=0,02)$ e de vibriões $(\mathrm{R}=0,53 ; \mathrm{p}=0,03)$. Foram encontradas diferenças espaciais significativas de biomassa (Mann Whitney: $\mathrm{p}=0,01$ ) e volume celular dos morfotipos (Mann Whitney: $\mathrm{p}=0,003$ ), entre os locais de coleta. As fortes correlações positivas da temperatura da água e do oxigênio, com o bacterioplâncton, são sugestivas de uma provavelmente elevada atividade bacteriana nesse sistema.

\section{REFERENCES}

Amblard, C.; Bourdier, G.; Carrias, J. F.; Marine, N.; Quiblier, C., (1996), Évolution saisonnière de la structure des communautés microbiennes dans un reservoir d`eau potable. Water Research 30: 613-624. 
American Public Health Association, (1998), Standard Methods for the examination of water and wastewater. $20^{\text {th }}$ Edition. APHA, Washington, DC, $1314 \mathrm{p}$.

Azam, F, Fenchel, T., Field, J. G., Gray, J. S., MeyerReil, L. A., Thingstad, F. (1983), The ecological role of water-column microbes in the sea. Mar. Ecol. Prog. Ser. 10, 257-263.

Bratbak, G. (1993), Microscopic methods for measuring bacterial biovolume: epifluorescence microscopy, scanning electron microscopy and transmission electron microscopy. In: Kemp P. F.; Sherr B. F.; Sherr E. B. and Cole, J. J. (Eds.). Handbook of Methods in Aquatic Microbial ecology. Lewis Publishers, London. pp. 309-317.

Carvalho, P., Thomaz, S. M., Bini, L. M. (2003), Effects of water level, abiotic and biotic factors on bacterioplankton abundance in lagoons of a tropical floodplain (Paraná River, Brazil). Hydrobiologia 510, 67-74.

Castillo, M. M.; Kling, G. W.; Allan, J. D. (2003), Bottom-up controls on bacterial production in tropical lowland rivers. Limnol. Oceanogr. 48: 1466-1475.

Coveney, M. F.; Wetzel, R. G. (1995), Biomass, production and specific growth rate of bacterioplankton in an oligotrophic lake. Limnol. and Oceanogr. 40, 1187-1200.

Crump, B. C., Kling, G. W., Bahr, M., Hobbie, J. E. (2003), Bacterioplankton community shifts in an artic lake correlate with seasonal changes in organic matter source. Appl. Environ. Microbiol. 2253-2268.

del Giorgio, P. A., Cole, J. J. (1998), Bacterial growth efficiency in natural aquatic systems. Annu. Rev. Ecol. Syst. 29, 503-541.

del Giorgio, P. A., Gasol, J. M. (1995), Biomass distribution in freshwater plankton communities. The American naturalist 146, 135-152.

Erikson, R., Vammen, K., Zelaya, A., Bell, R. (1999), Distribution and dynamics of bacterioplankton production in a polymictic tropical lake (Lago Xolotlán, Nicaragua). Hydrobiologia 382, 27-39.

Farjalla, V. F., Faria, B. M., Esteves, F. A., Bozelli, R. L. (2001), Bacterial density and biomass, and relations with abiotic factors, in 14 coastal lagoons of Rio de Janeiro state. Oecologia brasiliensis vol. IX, 65-76.

Fuhrman, J. A. (1999), Marine viruses and their biogeochemical and ecological effects. Nature 399: 541-548.

Gocke, K., Rheinheimer, G. (1988), Microbial investigations in rivers VII. Seasonal variations of bacterial numbers and activity in eutrophied rivers of Northern Germany. Arch. Hydrobiol. 112, 197-219.

Golterman, H. L., Clymo, R. S., Onstad, M.A.M. (1978), Methods for Physical and Chemical Analysis of Freshwaters. Blackwell Scientific Publications. Oxford. $231 \mathrm{p}$.
Gonzalez, A. M.; Paranhos, R.; Andrade, L.; Valentin, J. L. (2000). Bacterial production in Guanabara Bay (Rio de janeiro, Brazil) evaluated by ${ }^{3} \mathrm{H}$-leucina incorporation. Brazilian Archives of Biology and Technology. 43, 493-500.

Guimarães-Segundo, J. E. A. (2002), Diagnóstico geoquímico ambiental de água e sedimento de fundo do rio Pitimbu, região sul da grande Natal (RN).[Dissertation]. Natal: Federal University of Rio Grande do Norte. 178 p.

Gurung, T. B., Urabe, J., Nozaki, K., Yoshimizu, C., Nakanishi, M. (2002), Bacterioplankton production in a water column of Lake Biwa. Lakes and Reservoirs 7, 317-323.

Izaguirre, I., Allende, L., Marinone, M. C. (2003), Comparative study of the planktonic communities of three lakes of contrasting trophic state at Hope Bay (Antartic Península). J. Plankton Res. 25, 1079 1097.

Jezbera, J., Nedoma, J., Simek, K. (2003), Longitudinal changes in protistan bacterivory and bacterial production in two canyon-shaped reservoirs of different trophic status. Hydrobiologia 504, 115-130.

Jugnia, L. B., Tadanléké, R. D., Sime-Ngando, T., Foto, S. M., Kemka, N. (1998), Short-term variations in the abundance and cell volume of bacterioplankton in an artificial tropical lake. Hydrobiologia 385, 113-119.

Jurgens, K., Pernthaler, J., Schalla, S., and Amann, R. (1999), Morphological and compositional changes in a planktonic bacterial community in response to enhanced protozoan grazing. Appl. Environ. Microbiol. 65, 1241-1250,

Kirschner, A. K. T., Velimirov, B. (1997), A seasonal study of bacterial community succession in a backwater system, indicated by variation in morphotype numbers, biomass and secondary production. Microb. Ecol. 34, 27-38.

Kisand, V., Tuvikene, L., Nõges, T. (2001), Role of phosphorus and nitrogen for bacteria and phytoplankton development in a large shallow lake. Hydrobiologia 457, 187-197.

Krstulovic, N., Solic, M., Marasovic, I., (1997), Relationship between bacteria, phytoplankton and heterotrophic nanoflagellates along the trophic gradient. Helgolander Meeresunters 51, 433-443.

Leff, L. G. (2000), Longitudinal changes in microbial assemblages of the Ogeechee River. Freshwater Biol. 43, 605-615.

Leff, L. G., Leff, A. A., Lemke, M. J. (1998), Seasonal changes in planktonic bacterial assemblages of two Ohio streams. Freshwater Biol. 39, 129-134.

Lewis, W. M., Frost, T., Morris, D. (1986), Studies of planktonic bacteria in Lake Valencia, Venezuela. Arch. Hydrobiol. 106, 289-305. 
Lind, O. T., Barcena, E. (2003), Response of riverine and transition zone bacterioplankton communities to a pulsed river inflow. Hydrobiologia 504, 79-85.

Lindström, E. S. (2001), Investiganting influential factors on bacterioplankton community composition: results from a field study of five mesotrophic lakes. Microb. Ecol. 42, 598-605.

Liu, J., Leff, L. G. (2002), Temporal changes in the bacterioplankton of a Northeast Ohio (USA) River. Hydrobiologia 489, 151-159.

Lorenzen, C. F. (1967), Determination of chlorophyll and phaeopigments: spectrophotometric equations. Limnology and Oceanography 16, 990 - 992.

Masín, M., Jezbera, J., Nedoma, J., Stráskrabová, V., Hejslar, J., Simék, K. (2003), Changes in bacterial community composition and microbial activities along the longitudinal axis of two canyon-shaped reservoirs with different inflow loading. Hydrobiologia 504, 99-113.

Muylaert, K., Van der Gucht, K., Vloemans, N., Meester, L., Gillis, M., Vyverman, W. (2002), Relationship between bacterial community composition and bottom-up versus top-down variables in flour eutrophic shallow lakes. Appl. Environ. Microbiol. 68, 4740-4750.

Norland, S. (1993), The relashionship between biomass and volume of bacteria. In: Kemp P. F.; Sherr B. F.; Sherr E. B. and Cole, J. J. (Eds.). Handbook of Methods in Aquatic Microbial ecology. Lewis Publishers, London. pp. 303-307.

Oliveira, F. G. (1994), Autodepuração e monitoramento do Rio Pitimbu. Dissertation, Universidade Federal do Rio Grande do Norte, Natal, Brazil.

Palumbo, A. V., Fergusson, R. L., Rublee, P. (1984), Size of suspended bacterial cells and association of heterotrophic activity of particles in estuarine and coastal waters. Appl. Environ. Microbiol. 48, 157 164.
Petrucio, M. M.; Barbosa, F. A. R.; Thomaz, S. M. (2005). Bacteria and phytoplankton production rates in eight rivers stretches of the middle Rio Doce.Hydrographic basin (Southeast Brazil). Brazilian Archives of Biology Technology Vol. 48, $487-496$.

Posch, T., Loferer-Krößbacher, M., Gao, G., Alfreider, A., Pernthaler, J., Psenner, R. (2001), Precision of bacterioplankton biomass determination: a comparison of two fluorescent dyes, and of allometric and linear volume-to-carbon conversion factors. Aquat. Microb. Ecol. 25, 55-63.

Seleghim, M. H. R. (1992), Flutuações nas comunidades planctônicas e bentônicas de um ecossistema artificial raso (Represa do MonjolinhoSão Carlos-SP) com ênfase nas populações de protozoários e bactérias. Dissertação, Universidade Federal de São Carlos, São Carlos, Brasil.

Sime-Ngando, T., Bourdier, G., Amblard, C., PinelAlloul, B. (1991), Short-term variations in specific biovolumes of different bacterial forms in aquatic ecosystems. Microb. Ecol. 21, 211-226.

Simon, M.; Azam, F. (1989), Protein content and protein synthesis rates of planktonic marine bacteria. Mar. Ecol. Prog. Ser. 51, 201-213.

Valderrama, J. C. (1981), The simultaneous analysis of total nitrogen and total phosphorus on natural waters. Mar. Chem. 10, 109 - 122.
Received: November 08, 2005; Revised: November 13, 2006; Accepted: July 27, 2007. 